American Journal of Applied Sciences 6 (5): 902-912, 2009

ISSN 1546-9239

(C) 2009 Science Publications

\title{
The First Report of the Occurrence of Anthracnose Disease Caused by Colletotrichum gloeosporioides (Penz.) Penz. \& Sacc. on Dragon Fruit (Hylocereus spp.) in Peninsular Malaysia
}

\author{
${ }^{1}$ Masanto Masyahit, ${ }^{1}$ Kamaruzaman Sijam, ${ }^{2}$ Yahya Awang and ${ }^{3}$ Mohd Ghazali Mohd Satar \\ ${ }^{1}$ Department of Plant Protection, Faculty of Agriculture, \\ University Putra Malaysia, 43400 UPM Serdang, Selangor Darul Ehsan, Malaysia \\ ${ }^{2}$ Department of Crop Science, Faculty of Agriculture, \\ University Putra Malaysia, 43400 UPM Serdang, Selangor Darul Ehsan, Malaysia \\ ${ }^{3}$ Department of Soil Science, Faculty of Agriculture, \\ University Putra Malaysia, 43400 UPM Serdang, Selangor Darul Ehsan, Malaysia
}

\begin{abstract}
Problem statement: The increasing of dragon fruit (Hylocereus spp.) plantations in Malaysia enhances the researches on this crop, particularly focusing on its physico-chemical characteristics, great potential health benefits and nutritional value. However, its scientific report of disease is still lacking, primarily on anthracnose disease. This study was then conducted to investigate the distribution of anthracnose disease on dragon fruit and to correlate its occurrence with weather and cultural data. Approach: Survey and sampling were conducted on dragon fruit-growing areas in Peninsular Malaysia since December 2007 until August 2008 to measure the Disease Incidence (DI) and Disease Severity (DS). The diseased stem and fruit were sampled and brought to laboratory for isolation and identification. DI data were plotted with DS and then correlated using Pearson correlation with weather and cultural data. Results: Of the 43 surveyed-farms in 11 states, DI and DS were successfully recorded on three dragon fruit species from 36 farms (83.72\%). The infected stem and fruit had reddish-brown lesions with chlorotic haloes symptoms. The lesion had brown centers and coalesced to rot. Based on its whitish-orange colony, septated hypae and capsule-like conidia and the pathogenicity test, the pathogen was identified as Colletotrichum gloeosporioides. One way ANOVA with DMRT test highlighted that the most disease occurrence was found in Malacca (mean of DI and DS, 57.30 and $21.20 \%$ ), whereas the lowest in Kelantan state (mean of DI and DS, 6.70 and $4.30 \%$ ). Pearson coefficient correlations were around 0.107-0.261 for relationships between disease occurrence and age of crops and acreage of farm, from- 0.049 to- 0.237 for disease prevalence with relative humidity and rainfall and around-0.012-0.173 for disease occurrence with monthly temperature, wind velocity and altitude. Conclusion: The occurrence of anthracnose on dragon fruit in Peninsular Malaysia was more influenced by environmental conditions and agricultural practices rather than climatic factors.
\end{abstract}

Keywords: disease incidence, disease severity, pitaya

\section{INTRODUCTION}

The dragon fruit (Hylocereus spp.) is a tropical climbing cactus which is also known as pitaya or pitahaya (Latin America), strawberry pear and night blooming cereus (English) ${ }^{[1-3]}$ and mata naga (Malaysia). Currently, this plant has been commercially cultivating in Australia ${ }^{[4]}$, Brazil ${ }^{[5]}$, Colombia ${ }^{[6]}$, Costa Rica $^{[7]}$, Egypt ${ }^{[8]}$, Israel ${ }^{[9]}$, Japan ${ }^{[10]}$, Mauritius ${ }^{[11]}$, Mexico $^{[12]}$, Nicaragua ${ }^{[13]}$, Taiwan ${ }^{[14]}$, the $\operatorname{USA}^{[15]}$ and
Vietnam $^{[16]}$. In Malaysia, dragon fruit has been initially introduced on large scale at the end of 1990s by Golden Hope Company at Sungai Wangi Estate, Perak. Until 2006, Malaysia has around 927.4 ha (363.2 ha production areas) dragon fruit-growing areas with total production about 2,534.2 tons (production value around US\$3.5 million) and Johor has the largest areas, 326.7 $\mathrm{ha}^{[17]}$. In addition to some abiotic disorders such as sunburn $^{[17]}$, very strong wind or hurricanes ${ }^{[2]}$, high summer temperature ${ }^{[18]}$, chilling injury, mechanical

Corresponding Author: Kamaruzaman Sijam, Department of Plant Protection, Faculty of Agriculture, University Putra Malaysia, 43400 UPM Serdang, Selangor Darul Ehsan, Malaysia 
Am. J. Applied Sci., 6 (5): 902-912, 2009

injury and water loss ${ }^{[3]}$; the cultivation of dragon fruit is also influenced by the infestation of pests and diseases.

Several diseases affecting white-fleshed dragon fruit (Hylocereus undatus) in many places have been scientifically reported, such as cactus virus $\mathrm{X}^{[19]}$, stem rot and fruit rot in Taiwan ${ }^{[20]}$ and Japan ${ }^{[21]}$, stem spots in Mexico ${ }^{[22]}$ and anthracnose disease in $\operatorname{Japan}^{[23]}$ and the USA ${ }^{[24]}$. Anthracnose disease also infected yellow species of dragon fruit (H. megalanthus syn. Selenicerus megalanthus) in Brazil ${ }^{[25]}$. In Okinawa Perfecture, Japan, Taba et al. ${ }^{[23]}$ not only observed anthracnose causing water-soaked lesion on $H$. undatus species but also found Salmon-colored conidial masses on diseased fruit. This disease has been successfully recorded in Miami-Dade County, Florida, the USA since December 2004 on the same crop as well ${ }^{[24]}$. Meanwhile, in the State of São Paulo, Brazil, Colletotrichum anthracnose has been reported causing a loss of up to $5 \%$ on yellow pitahaya ${ }^{[25]}$. Those three reports, however, neither correlated the anthracnose occurrence with environmental or cultural data.

Most of researches on dragon fruit in Malaysia more focused on its physico-chemical characteristics $^{[26-28]}$, great potential health benefits ${ }^{[29]}$ and nutritional value ${ }^{[30-32]}$; whereas the scientific documentation particularly regarding diseases on dragon fruit in Malaysia is still lacking ${ }^{[33]}$. The recent report is Fusarium disease on red-fleshed dragon fruit (H. polyrhizus) in Malaysia ${ }^{[34]}$ and there is no report of anthracnose disease on dragon fruit in this country. This study, therefore, was carried out to study the occurrence and distribution of anthracnose disease on dragon fruit in Peninsular Malaysia as well as to correlate its occurrence with weather and cultural data.

\section{MATERIALS AND METHODS}

Assessment of disease occurrence: Survey and sampling were concurrently carried out on dragon fruitgrowing areas in Peninsular Malaysia since December 2007 until August 2008. Fifty posts of dragon fruit crops from each surveyed-orchard (at least with 0.4 ha in acreage) were randomly sampled to assess the disease occurrence. The Disease Incidence (DI) was measured using this following equation ${ }^{[35]}$ :

$$
\text { DI }=\frac{\text { Number of inf ected plant units }}{\text { Total number of plant units assessed }} \times 100 \%
$$

Meanwhile, the Disease Severity (DS) was determined according to alternative rating scale proposed by Bowen ${ }^{[36]}$ in which scale $0=$ no symptom, scale $1=0-20 \%$ disease severity range, scale $2=20$ -
$40 \%$, scale $3=40-60 \%$, scale $4=60-80 \%$ and scale $5=80-100 \%$, respectively. DS was measured using the equation proposed by $\mathrm{Kranz}^{[37]}$ as follows:

$$
\mathrm{DS}=\frac{\sum(\mathrm{a} \times \mathrm{b})}{\mathrm{N} . \mathrm{Z}} \times 100 \%
$$

$\Sigma(\mathrm{a} \times \mathrm{b})=$ Sum of the symptomatic plant and their corresponding score scale

$\mathrm{N}=$ Total number of sampled plant

$\mathrm{Z} \quad=$ Highest score scale

Longitude and altitude data from surveyed area were recorded using GPS device (SILVA MultinavVersion 2.01). Cultural data including age of crops and acreage of farms were also noted.

Isolation and identification of pathogen: Infected samples of dragon fruit were collected and brought to laboratory for isolation on Potato Dextrose Agar (PDA) plates and for further identification morphological characteristics such as colony, mycelia as well as shape and size of conidia under light microscopy observation.

Pathogenicity test: This test was carried out in vitro on both healthy stem and fruit, according to method developed by Melanie and colleagues ${ }^{[38]}$ with a slight modification. The isolated pathogen was cultured within Potato Dextrose Broth (PDB) medium and incubated for a week at $150 \mathrm{rpm}$ rotary shaker. Conidia were harvested by filtering them through four layers of cheesecloth to remove mycelia. Conidia concentration was then determined using a hemacytometer and adjusted to $1 \times 10^{6}$ conidia per $\mathrm{ml}$ using Sterile Distilled Water (SDW).

The fresh and healthy organs were surfacedisinfected for $2 \mathrm{~min}$ with $1 \%$ sodium hypochlorite $(\mathrm{NaOCl})$. Artificial wounds approximately $2 \mathrm{~mm}$ deep on organ were aseptically made using sterile sharppointed tooth stick. Twenty microliters of conidia suspension was inoculated into the wounded site of the plant part using sterile fine-syringe needle. The inoculated organs were placed into the moisturized filter paper-layered trays and then wrapped with transparent wrapping plastic. They were incubated at room temperature in the laboratory for 2 weeks and the symptoms development was observed thrice a week.

Statistical data analysis: DI and DS data were first plotted and pooled together using Microsoft Excel 2003 Program. To achieve the best linear severityincidence ${ }^{[39]}$, test of normality was employed to determine whether data should be transformed or not 
prior to analysis. One way ANOVA with DMRT test was performed to obtain significant distribution of DI and DS amongst surveyed states by using SPSS Program, Version $15.0^{[40]}$. Regression analysis was also performed to correlate disease occurrence with weather factors (1998-2008 period) such as temperature, Relative Humidity (RH), rainfall and wind velocityobtained from Malaysia Meteorological Department-as well as altitude, age of crops and acreage of farm.

\section{RESULTS}

Assessment of disease occurrence: During the surveys, the present study found that the red-fleshed species (H. polyrhizus) was planted nationwide in Peninsular Malaysia, i.e., $90.7 \%$ of the surveyed farms (Table 1). Both red-fleshed and white-fleshed species (H. undatus) were intercropped together in Ayer Hangat, Langkawi (Kedah) and Batang Merbau (Kelantan). The combination of red-fleshed and yellow species (Selenicereus megalanthus) was only found in Pokok Sena (Kedah); whilst these three species were cultivated in one farm in Mersing (Johor). Among those species, the anthracnose disease was more frequently found on red-fleshed one rather than on white-fleshed (in Ayer Hangat, Kedah and Mersing, Johor) and yellow species (in Mersing, Johor).

The occurrence of anthracnose disease was successfully recorded from 36 farms $(83.72 \%)$ of the 43 farms surveyed from 11 states in Peninsular Malaysia. Despite of the highest incidence $(80 \%)$ occurred in Pekan, Pahang; the most severe disease $(32.0 \%)$ arose in Durian Tunggal, Malacca (Table 1).

Most of dragon fruit-growing areas in Peninsular Malaysia (37.20\%), as shown in Table 1, were located nearby the rubber plantation from which the incidence of anthracnose disease could be recorded from 13 farms with such environmental condition (81.25\%). The others were village situation, $25.58 \%$; intercropped with other crops, 20.93\%; experimental plot, 6.97\%; village forest, $4.65 \%$; and opened high hills and rice field, 2.32 and $2.32 \%$, respectively.

Isolation and identification of pathogen: Anthracnose disease on dragon fruit was characterized with reddishbrown lesions and chlorotic haloes symptoms on stem as well as fruit (Fig. 1a and b). These lesions had brown centers and then coalesced to rot. On the fruit, symptoms could increasingly develop at post harvest condition in the moisturized store room. In the field, the aservuli were found as the dark concentric circle on the infected stem (Fig. 1c). The identification of isolated pathogen described that the fungus had whitish-orange colony (Fig. 1d), with septated hypae, circled aservuli bearing conidia on conidiogenous cells and capsule-like conidia (6-10 $\times 2-2.5 \mu \mathrm{m}$ in size) containing one cell (Fig. 1e and f). According to Sutton ${ }^{[41]}$, this pathogenic fungus was then characterized as Colletotrichum gloeosporioides (Penz.) Penz. \& Sacc.

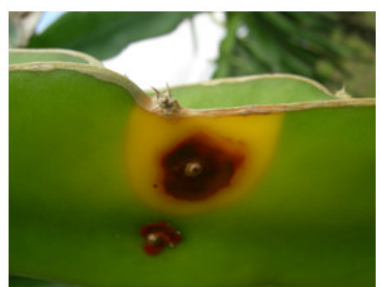

(a)

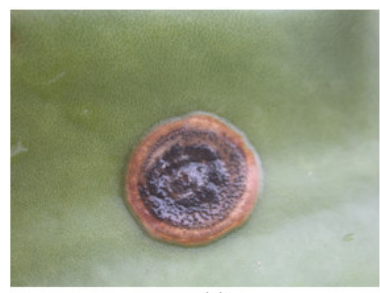

(c)

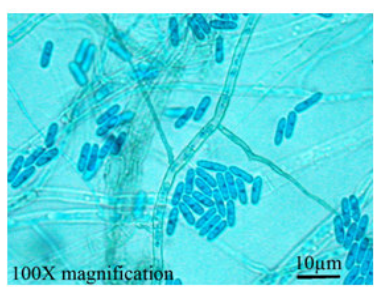

(e)

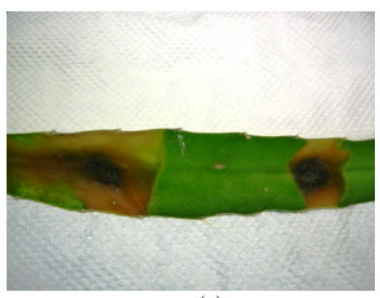

(g)

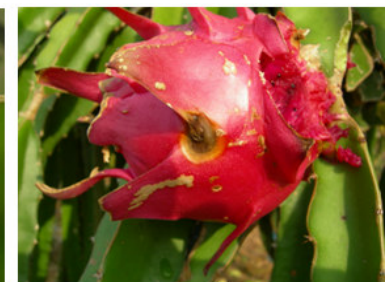

(b)

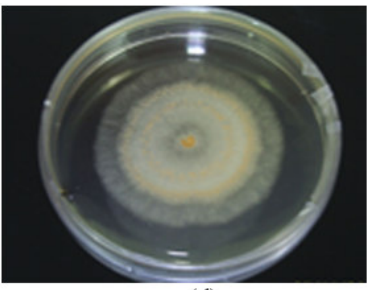

(d)

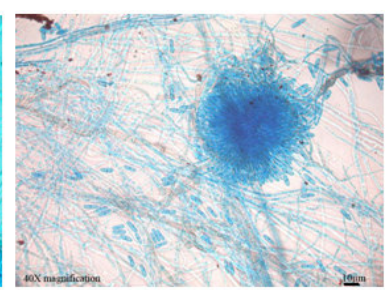

(f)

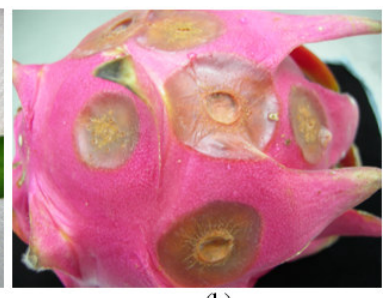

(h)
Fig. 1: (a): Disease symptom on infected stem (b): Symptoms on infected fruit; (c): Aservuli of $C$. gloeosporioides on infected stem; (d): Colony on PDA, (e): Conidia and hyphae; (f): Aservuli bearing conidia; (g): Disease symptoms on the inoculated stem and (h): Symptoms appearing on inoculated fruit for pathogenicity test 
Am. J. Applied Sci., 6 (5): 902-912, 2009

Table 1: Occurrence of anthracnose disease recorded from 43 of surveyed dragon fruit-growing areas in Peninsular Malaysia

\begin{tabular}{|c|c|c|c|c|c|c|c|}
\hline Location $^{\mathrm{a}}$ & $\begin{array}{l}\text { Dragon fruit } \\
\text { species }\end{array}$ & $\begin{array}{l}\text { Farm } \\
\text { environment }\end{array}$ & $\begin{array}{l}\text { Altitude } \\
\text { (m asl) }\end{array}$ & $\begin{array}{l}\text { Age } \\
\text { (years) }^{\mathrm{b}}\end{array}$ & $\begin{array}{l}\text { Acreage } \\
(\text { ha })^{\text {c }}\end{array}$ & $\begin{array}{l}\text { Incidence } \\
(\%)\end{array}$ & $\begin{array}{l}\text { Severity } \\
(\%)\end{array}$ \\
\hline \multicolumn{8}{|l|}{ Johor } \\
\hline Batu Pahat & $\mathrm{Rf}(\mathrm{Hp})$ & Rubber plantation & 12.50 & 4.50 & 1.42 & $0(0.00)^{\mathrm{d}}$ & 0.0 \\
\hline Kluang & $\mathrm{Rf}(\mathrm{Hp})$ & Rubber plantation & 81.38 & 4.00 & 1.42 & $60(7.75)$ & 18.4 \\
\hline Mersing & Rf (Hp), Wf (Hu), Ys (Sm) & Opened high hills & 47.55 & 6.00 & 10.11 & $56(7.48)$ & 14.0 \\
\hline \multicolumn{8}{|l|}{ Malacca } \\
\hline Durian Tunggal & $\operatorname{Rf}(\mathrm{Hp})$ & Rubber plantation & 10.36 & 6.00 & 3.24 & $76(8.72)$ & 32.0 \\
\hline Machap Umboo & Rf (Hp) & Rubber plantation & 61.26 & 5.00 & 2.43 & $46(6.78)$ & 15.2 \\
\hline Naning & $\operatorname{Rf}(\mathrm{Hp})$ & Rubber plantation & 42.36 & 1.50 & 1.21 & $52(7.21)$ & 16.4 \\
\hline \multicolumn{8}{|l|}{ Negeri sembilan } \\
\hline Rembau & $\operatorname{Rf}(\mathrm{Hp})$ & Village situtation & 54.56 & 1.50 & 0.48 & $28(5.29)$ & 5.6 \\
\hline Kuala Pilah & Rf (Hp) & Rubber plantation & 80.77 & 1.50 & 2.83 & $58(7.62)$ & 12.0 \\
\hline Pajam & $\operatorname{Rf}(\mathrm{Hp})$ & Rubber plantation & 60.96 & 2.50 & 2.43 & $60(7.75)$ & 18.4 \\
\hline \multicolumn{8}{|l|}{ Selangor } \\
\hline Sepang & $\mathrm{Rf}(\mathrm{Hp})$ & Village situation & 51.20 & 3.00 & 0.65 & $0(0.00)$ & 0.0 \\
\hline Hulu Langat & $\operatorname{Rf}(\mathrm{Hp})$ & Rubber plantation & 75.90 & 0.67 & 2.43 & $46(6.78)$ & 13.6 \\
\hline \multirow{2}{*}{\multicolumn{8}{|c|}{ Perak }} \\
\hline & & & & & & & \\
\hline Slim River & Rf (Hp) & Rubber plantation & 44.50 & 4.00 & 0.81 & $36(6.00)$ & 11.2 \\
\hline Teluk Intan & $\mathrm{Rf}(\mathrm{Hp})$ & Village situation & 5.80 & 4.00 & 0.4 & $36(6.00)$ & 10.8 \\
\hline Tapah & $\mathrm{Rf}(\mathrm{Hp})$ & Rubber plantation & 40.54 & 3.50 & 0.81 & $36(6.00)$ & 10.0 \\
\hline Batu Gajah & $\mathrm{Rf}(\mathrm{Hp})$ & Rubber plantation & 42.36 & 2.50 & 0.61 & $36(6.00)$ & 11.2 \\
\hline Pantai Remis & $\mathrm{Rf}(\mathrm{Hp})$ & Intercropping & 6.40 & 1.50 & 2.43 & $28(5.29)$ & 6.8 \\
\hline Taiping & $\mathrm{Rf}(\mathrm{Hp})$ & Intercropping & 20.42 & 1.00 & 0.81 & $48(6.93)$ & 12.0 \\
\hline \multicolumn{8}{|l|}{ Pahang } \\
\hline Pekan & $\operatorname{Rf}(\mathrm{Hp})$ & Village forest & 11.88 & 3.00 & 4.45 & $80(8.94)$ & 28.8 \\
\hline Kuantan & $\mathrm{Rf}(\mathrm{Hp})$ & Urban situation & 17.37 & 4.00 & 2.02 & $16(4.00)$ & 4.8 \\
\hline Raub & $\operatorname{Rf}(\mathrm{Hp})$ & Rubber plantation & 146.91 & 4.00 & 3.64 & $38(6.16)$ & 11.2 \\
\hline Jerantut & $\mathrm{Rf}(\mathrm{Hp})$ & Rubber plantation & 121.31 & 0.50 & 1.62 & $28(5.29)$ & 9.2 \\
\hline \multicolumn{8}{|l|}{ Terengganu } \\
\hline Paka & Rf (Hp) & Intercropping & 8.53 & 0.60 & 0.48 & $40(6.32)$ & 12.4 \\
\hline Merchang & $\mathrm{Rf}(\mathrm{Hp})$ & Village situation & 6.09 & 3.00 & 1.01 & $32(5.66)$ & 9.2 \\
\hline Marang & Rf (Hp) & Intercropping & 4.57 & 2.50 & 2.02 & $0(0.00)$ & 0.0 \\
\hline Setiu & $\operatorname{Rf}(\mathrm{Hp})$ & Intercropping & 5.79 & 1.50 & 0.40 & $0(0.00)$ & 0.0 \\
\hline Kerteh & Rf (Hp) & Village situation & 11.27 & 2.50 & 0.81 & $12(3.46)$ & 4.0 \\
\hline \multicolumn{8}{|l|}{ Kelantan } \\
\hline Batang Merbau & Rf $(\mathrm{Hp})$ and Wf $(\mathrm{Hu})$ & Experimental plot & 51.81 & 3.00 & 0.40 & $0(0.00)$ & 0.0 \\
\hline Kota Bharu & $\operatorname{Rf}(\mathrm{Hp})$ & Experimental plot & 10.97 & 2.00 & 0.40 & $26(5.10)$ & 7.2 \\
\hline Gua Musang & $\mathrm{Rf}(\mathrm{Hp})$ & Rubber plantation & 31.67 & 4.00 & 1.21 & $0(0.00)$ & 0.0 \\
\hline Kuala Krai & $\mathrm{Rf}(\mathrm{Hp})$ & Village forest & 34.74 & 2.00 & 2.02 & $28(5.29)$ & 10.0 \\
\hline \multicolumn{8}{|l|}{ Pulau pinang } \\
\hline Bukit Mertajam & $\mathrm{Rf}(\mathrm{Hp})$ & Village situation & 30.78 & 3.00 & 2.02 & $48(6.93)$ & 12.8 \\
\hline Seberang Perai Tengah & $\mathrm{Rf}(\mathrm{Hp})$ & Village situation & 22.55 & 1.50 & 0.81 & $28(5.29)$ & 7.6 \\
\hline Seberang Perai Utara & Rf (Hp) & Intercropping & 9.44 & 5.00 & 5.95 & $28(5.29)$ & 9.6 \\
\hline \multicolumn{8}{|l|}{ Kedah } \\
\hline Merbau Pulas & $\operatorname{Rf}(\mathrm{Hp})$ & Village situation & 14.63 & 0.58 & 0.40 & $0(0.00)$ & 0.0 \\
\hline Pokok Sena & $\operatorname{Rf}(\mathrm{Hp})$ and $\mathrm{Ys}(\mathrm{Sm})$ & Rubber plantation & 19.81 & 0.40 & 0.40 & $6(2.45)$ & 2.0 \\
\hline Gurun & $\mathrm{Rf}(\mathrm{Hp})$ & Intercropping & 25.60 & 2.00 & 2.43 & $0(0.00)$ & 0.0 \\
\hline Yan & $\mathrm{Rf}(\mathrm{Hp})$ & Intercropping & 3.96 & 2.00 & 0.40 & $18(4.24)$ & 5.2 \\
\hline Ayer Hitam & $\operatorname{Rf}(\mathrm{Hp})$ & Rice field & 3.35 & 2.00 & 0.81 & $68(8.25)$ & 29.2 \\
\hline Mata Ayer & Rf (Hp) & Rubber plantation & 28.95 & 3.50 & 2.02 & $0(0.00)$ & 0.0 \\
\hline Pantai Kok & Rf (Hp) & Village situation & 27.43 & 1.50 & 0.40 & $58(7.62)$ & 21.2 \\
\hline Ayer Hangat & $\mathrm{Rf}(\mathrm{Hp})$ and $\mathrm{Wf}(\mathrm{Hu})$ & Experimental plot & 3.96 & 4.00 & 0.81 & $48(6.93)$ & 15.2 \\
\hline \multicolumn{8}{|l|}{ Perlis } \\
\hline Beseri & $\mathrm{Rf}(\mathrm{Hp})$ & Intercropping & 25.60 & 2.00 & 0.61 & $32(5.66)$ & 8.4 \\
\hline
\end{tabular}

${ }^{\mathrm{a}}$ : Locations were arranged successively from the northern (Johor, Malacca and Negeri Sembilan), western (Selangor and Perak), eastern (Pahang, Terengganu and Kelantan) and southern (Pulau Pinang, Kedah and Perlis). ${ }^{\text {b: }}$ Age of crops which were recorded until surveyed date; ${ }^{\mathrm{c}}$ : Generally, growers cultivated in acre acreage. 1 acre consists of approximately 449 posts in which 1 post has 4 plants. 1 acre $=0.4$ ha; ${ }^{d}$ : Square root transformation data; asl = above sea level; $\mathrm{Rf}=$ Red-fleshed species $(\mathrm{Hp}=$ Hylocereus polyrhizus $) ; \mathrm{Wf}=$ White-fleshed species $(\mathrm{Hu}=$ Hylocereus undatus $) ;$ Ys = Yellow species $(\mathrm{Sm}=$ Selenicereus megalanthus $)$

Pathogenicity test: The in vitro pathogenicity test resulted in the appearance of the anthracnose symptoms on both inoculated stem and fruit that similar to those found in the field. These typical anthracnose symptoms occurred on the fruit and the stem on second and third day after inoculation, respectively (Fig. $1 \mathrm{~g}$ and $\mathrm{h}$ ). 
Am. J. Applied Sci., 6 (5): 902-912, 2009

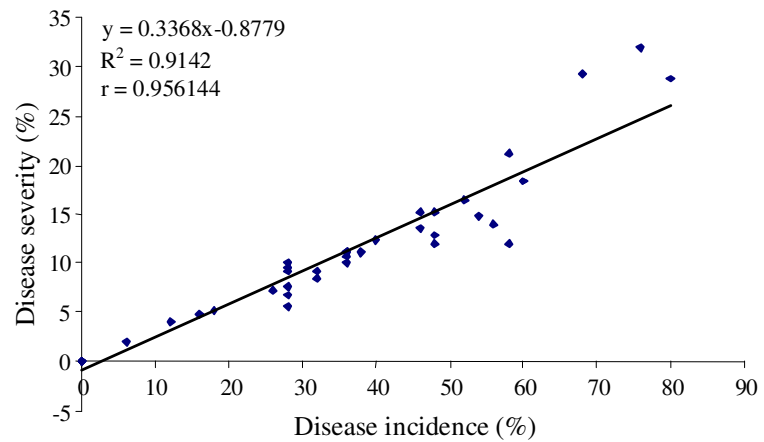

(a)

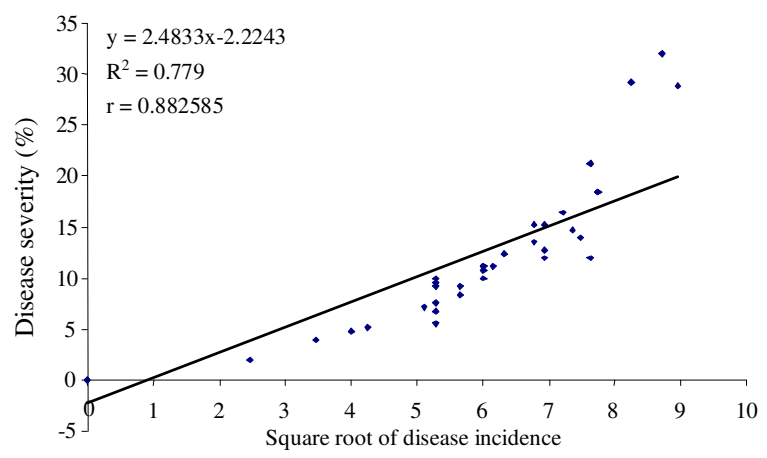

(b)

Fig. 2: Relationship between incidence and severity of anthracnose disease with (a): Untransformed and (b): Square root transformation of incidence data

The inoculated fruit became completely decaying on seventh day after inoculation, while the stem got severely rotting on tenth day after inoculation.

Statistical data analysis: The normality test of DI and DS data revealed that only DS data which was normally distributed, while DI data should be incorporated in square root transformation prior to further analysis. Relationship between DI and DS, either measured as untransformed or square root transformed data, positively revealed linear correlation with $r=0.956$ and $\mathrm{r}=0.882$, respectively (Fig. 2). Meanwhile, one way ANOVA with DMRT test highlighted that the most disease prevalence was found in Malacca state, with mean of DI and DS, $57.30 \% \pm 0.33$ and $21.20 \% \pm 5.41$, respectively; whereas the lowest disease occurrence was recorded from Kelantan state, with mean of DI and DS, $6.70 \% \pm 2.25$ and $4.30 \% \pm 2.54$, respectively (Table 2). The positive Pearson coefficient correlations were successively showed between disease occurrence and age of crops and acreage of farm, with range of $r$ value around 0.107-0.261. Conversely, relationship between disease prevalence and Relative Humidity $(\mathrm{RH})$ and rainfall resulted in negative Pearson coefficient correlations, with range of $\mathrm{r}$ value from-0.049 to-0.237.
Table 2: The distribution of anthracnose disease in Peninsular Malaysia

\begin{tabular}{lll}
\hline & \multicolumn{2}{c}{ Disease occurrence } \\
\cline { 2 - 3 } State & Disease incidence $(\%)$ & Disease severity $(\%)$ \\
\hline Johor & $25.70 \pm 6.40 \mathrm{ab} *$ & $10.80 \pm 5.54 \mathrm{ab}$ \\
Malacca & $57.30 \pm 0.33 \mathrm{a}$ & $21.20 \pm 5.41 \mathrm{a}$ \\
Negeri Sembilan & $47.33 \pm 0.62 \mathrm{ab}$ & $12.00 \pm 3.69 \mathrm{ab}$ \\
Selangor & $22.18 \pm 5.71 \mathrm{ab}$ & $9.460 \pm 4.74 \mathrm{ab}$ \\
Perak & $36.36 \pm 0.04 \mathrm{ab}$ & $10.33 \pm 0.75 \mathrm{ab}$ \\
Pahang & $37.21 \pm 1.08 \mathrm{ab}$ & $13.50 \pm 5.27 \mathrm{ab}$ \\
Terengganu & $9.480 \pm 1.79 \mathrm{ab}$ & $5.120 \pm 2.48 \mathrm{~b}$ \\
Kelantan & $6.700 \pm 2.25 \mathrm{~b}$ & $4.300 \pm 2.54 \mathrm{~b}$ \\
Pulau Pinang & $33.98 \pm 0.29 \mathrm{ab}$ & $10.00 \pm 1.51 \mathrm{ab}$ \\
Kedah & $13.54 \pm 1.58 \mathrm{ab}$ & $9.100 \pm 4.01 \mathrm{ab}$ \\
Perlis & $32.00 \pm 32.00 \mathrm{ab}$ & $8.400 \pm 8.40 \mathrm{ab}$ \\
\hline
\end{tabular}

*: Means followed with same letter are not significantly different on 95\% confidence interval $(\alpha=0.05)$ analyzed with one-way ANOVA with DMRT test

Table 3: Pearson correlation coefficient (r) between disease occurrence and weather and cultural data

\begin{tabular}{|c|c|c|c|c|c|c|c|}
\hline \multirow{2}{*}{\multicolumn{2}{|c|}{ Temperature }} & \multicolumn{3}{|c|}{ Weather conditions } & \multirow[b]{2}{*}{ Altitude } & \multirow[b]{2}{*}{$\begin{array}{l}\text { Acreage } \\
\text { of farm }\end{array}$} & \multirow[b]{2}{*}{$\begin{array}{l}\text { Age of } \\
\text { crops }\end{array}$} \\
\hline & & $\begin{array}{l}\text { Relative } \\
\text { humidity }\end{array}$ & & $\begin{array}{l}\text { Wind } \\
\text { velocity }\end{array}$ & & & \\
\hline$\overline{\mathrm{DI}}$ & -0.012 & -0.166 & -0.237 & 0.078 & 0.173 & 0.261 & 0.107 \\
\hline DS & 0.039 & -0.154 & -0.049 & 0.143 & 0.060 & 0.261 & 0.207 \\
\hline
\end{tabular}

There were few nearly zero correlations between disease occurrence and monthly temperature, wind velocity and altitude of the surveyed localities, with range of $r$ value around-0.012-0.173 (Table 3 ). We did not, however, found the significant correlation between disease occurrence and those factors, either at the 0.01 or at the 0.05 level.

\section{DISCUSSION}

This study could be likely considered as the first scientific report pertaining to the occurrence of Colletotrichum anthracnose disease on dragon fruit (Hylocereus spp.) in Peninsular Malaysia. Another disease note was reported by Masratul Hawa and her colleagues $^{[34]}$ who successfully proved Fusarium proliferatum as the pathogenic fungi causing brownish to reddish lesions on red-fleshed dragon fruit $(H$. polyrhizus). The three previous studies have noted the occurrence and the similar causal fungi of anthracnose disease on the white-fleshed species in Okinawa Prefecture, Japan ${ }^{[23]}$ and Miami-Dade County, the $\mathrm{USA}^{[24]}$ as well as on yellow species in Brazil ${ }^{[25]}$. This pathogen has been also reported infecting other cacti species in Korea, such as Cereus peruvianus (Peruvian apple cactus) and $C$. tetragonus ${ }^{[42]}$, Indian fig cactus [Opuntia ficus-indica (L.) Mill.] ${ }^{[43]}$ as well as causing Colletotrichum stem rot on graft-cacti including, $H$. 
Am. J. Applied Sci., 6 (5): 902-912, 2009

trigonus (three-angled cactus), Gymnocalycium mihanovichii and Chamaecereus silvestrii ${ }^{[44]}$.

Although this recent investigation highlighted that the pathogenic fungus, Colletotrichum gloeosporioides, produced similar symptoms and the same conidia shape, the size of conidia $(6.0-10 \times 2.0-2.5 \mu \mathrm{m})$ on PDA culture was slightly different compared to those previously found on white-fleshed species in Okinawa Prefecture, Japan and Miami-Dade County, the USA, i.e. $9.0-24 \times 3.0-4.5 \mu \mathrm{m}$ on PDA culture ${ }^{[23]}$ and $12.5-$ $17.5 \times 3.8-7.5 \mu \mathrm{m}$ on one-half strength acidified PDA culture $^{[24]}$, respectively; whereas the isolate infecting yellow species in Brazil had conidia 12.1-18.1×3.6-8.2 $\mu \mathrm{m}$ in size on PDA culture ${ }^{[25]}$. Unlike the isolated fungi from those three previous researches, our findings showed that the isolated fungus had whitish-orange colony.

Zero incidence of disease in 7 farms (16.27\%) reported in this study mostly not only occurred in the farms which located far away from infected area, but also in the well-applicated sanitation farms; while low disease occurrences were found in farms in which copper based-fungicide was regularly treated. Statistically, however, the lowest disease occurrence (mean of DI and DS, 6.70\% \pm 2.25 and $4.30 \% \pm 2.54$, respectively) was found in Kelantan state in where dragon fruit crops were planted in experimental plot of state agricultural department and in farmer orchards which were intensively managed.

Our results on relationship between DI and DS explained that DI increasingly affected the level of DS. Seem $^{[45]}$ noted that the relationship between these two plant disease assessments, incidence and severity, created an epidemiologically significant concept. Although the coefficient correlations of this relationship were close to 1 , namely 0.956 and 0.882 (Fig. 2), the survey data representing field condition described that the highest incidence was found in Pahang state, particularly in Pekan district; while the most severe disease was recorded in Malacca state, especially in Durian Tunggal district.

The highest DI occurred in Pekan (Pahang) probably due to the unfavorable environmental condition for crops. Weather data showed that this area had the highest monthly rainfall during 11-year period, i.e., $265.17 \mathrm{~mm}$ (Fig. 3). This condition might cause flood disaster on 2006 in this low land $(11.88 \mathrm{~m}$ asl in altitude) so that enabled the pathogen to survive under such favorable environmental condition and then infect other healthy crops in the farm. Several under field studies found that the dispersal of those conidia was highly influenced by water, primarily rain $\operatorname{splash}^{[46-48]}$.
This study, however, significantly found the highest disease occurrence in Malacca state (mean of DI and DS, $57.30 \% \pm 0.33$ and $21.20 \% \pm 5.41$, respectively), particularly in Durian Tunggal district. In fact the monthly rainfall in this state was very low, 77.5 mm (Fig. 3). We assumed that the most severe disease in this area likely due to unwell-sanitation farm. The farmer did not prune the damaged stems from infected plants and they tended to ignore debris of diseased stems around the farm. Some reports on other crops considered conidia produced from debris or dead leaves as the main source of of $C$. gloeosporioides inoculum which could rapidly initiate an epidemic once favorable conditions for dispersal and infection occurred ${ }^{[49,50]}$. Therefore, Le Bellec et al. ${ }^{[6]}$ recommended pruning all the damaged stems and those that were entangled with one another at the first year after dragon fruit planting. In addition, the combination of pruning, weeding and spading has been reported increasing healthy fruit per plant and yield per hectare as well as reducing anthracnose occurrence on mango for two consecutive years $^{[51]}$.

The $81.25 \%$ of incidence of anthracnose disease in the farms located near rubber plantation probably occurred since the capability of inoculum to survive on dead leaves of rubber for long time. The occurrence of anthracnose disease on rubber had been documented since $1972^{[52]}$. Goyut et al. ${ }^{[48]}$ reported that the conidia of C. gloeosporioides could disperse for several tens of meters in rubber tree. Rubber crops could provide canopies for dragon fruit farms as well, so that the micro climate in the farms could favor the disease development. This recent study, however, neither investigated those possibilities nor isolated pathogen from dead rubber leaves.

The relationship between disease occurrence and acreage of farm (DI and DS, $r=0.261$ ) was constantly significant amongst the other weakly positive correlations in this recent research (Table 3.). It might be interpreted that disease occurrence would increase on larger farms due to requiring more intensive maintenance. Although there was a nearly zero correlation between DI and age of crops $(r=0.107)$, we obtained a little correlation between DS and this factor ( $r=0.207)$. In the fields, we found that the disease occurred even on the youngest surveyed farm (5-month old) in Pokok Sena, Kedah.

The finding in this study also revealed a nearly no correlation between disease occurrence and wind velocity (DI, $r=0.078 ; \mathrm{DS}, \mathrm{r}=0.143$ ). As this pathogen has water-borne conidia, the role of wind velocity is less important in affecting disease progress, primarily increasing the dispersal of conidia. 
Am. J. Applied Sci., 6 (5): 902-912, 2009

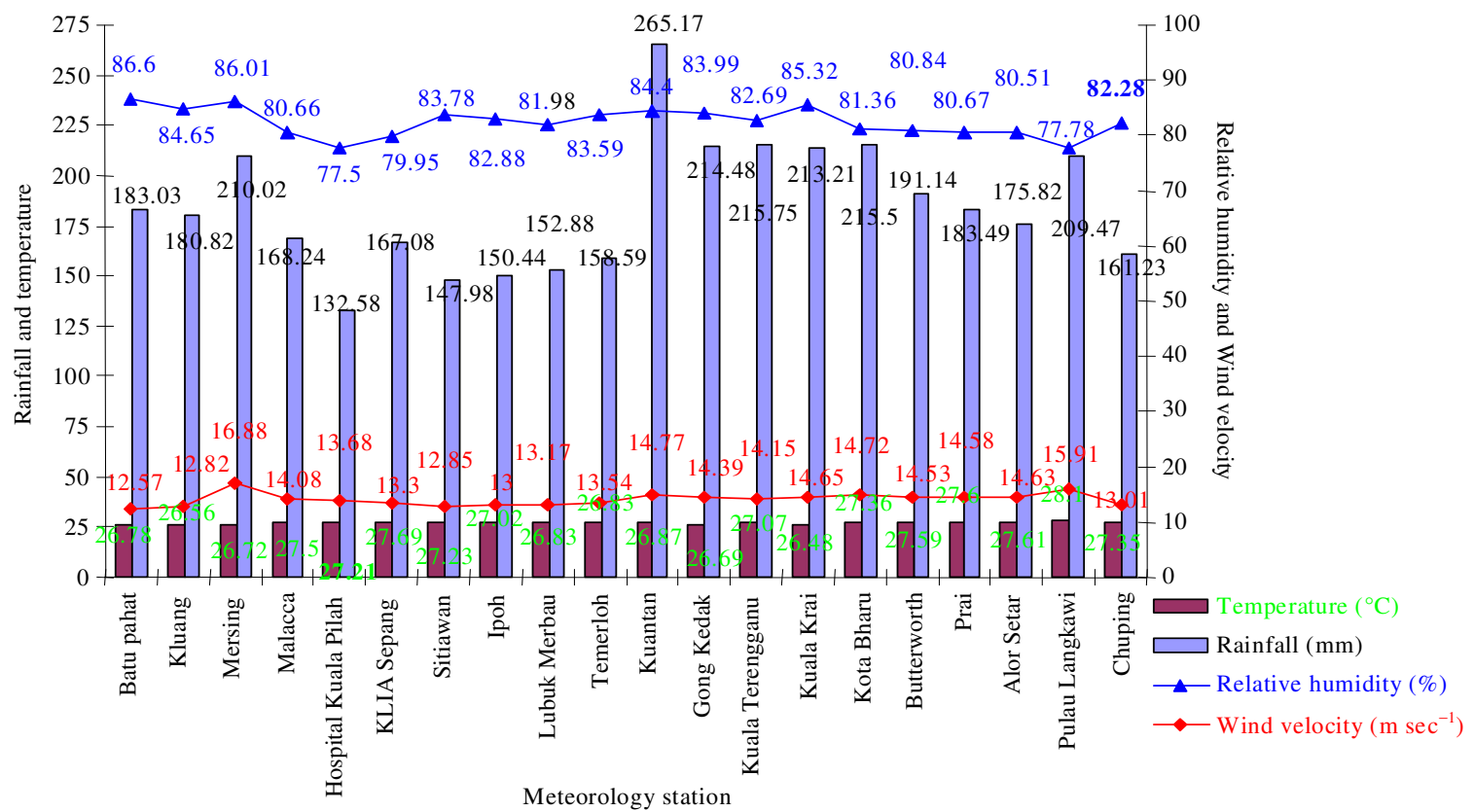

Fig. 3: The 11-year (1998-2008) of weather data in Peninsular Malaysia obtained from Department of Meteorological Malaysia

Agrios $^{[53]}$ noted that the wind could importantly influence the plant disease development by spreading inoculum of plant pathogen and accelerating the drying of wetness on the surfaces of plants surfaces and even become more important when it was assisted by rain.

In contrast with previous studies on $C$. gloeosporioides affecting cocoa ${ }^{[54]}$, Stylosanthes spp. ${ }^{[55]}$ and coconut palm ${ }^{[56]}$, this study did not linearly highlighted correlation between disease occurrence and temperature. Those three experiments reported that the incidence of $C$. gloeosporioides was significantly inhibited by the increase of temperature. Meanwhile, our findings on a quite negative relationship between disease occurrence and $\mathrm{RH}$ and rainfall did not parallel that of other studies on rubber ${ }^{[52]}$, citrus ${ }^{[57]}$, Stylosanthes spp. ${ }^{[55]}$ and coconut palm ${ }^{[56]}$ which found strongly positive correlations. The uncertain correlations of disease development and $\mathrm{RH}$ and rainfall, however, were highlighted on other previous investigations on Stylosanthes spp. ${ }^{[58,59]}$ and cocoa ${ }^{[54]}$.

Our investigations found that the anthracnose disease widely occurred in dragon fruit-growing areas in Peninsular Malaysia with range of monthly temperature and $\mathrm{RH}$, from $26.5-28.1{ }^{\circ} \mathrm{C}$ and 77.5 $86.6 \%$, respectively. It was in line with several authors who reported range of $20-30^{\circ} \mathrm{C}$ as the optimum temperature for the lesion development on rubber leaves ${ }^{[52]}$, in vitro disease development on Stylosanthes spp. ${ }^{[58]}$ as well as germination and production of conidia $^{[46]}$, appressoria production ${ }^{[47]}$, infection development ${ }^{[60]}$ and growth and sporulation ${ }^{[59]}$ of $C$. gloeosporioides on mango; but not similar with those who noted range of $\mathrm{RH}$ from $95-100 \%$ as the in vitro optimum RH for conidial production and germination as well as appressoria development of $C$. gloeosporioides on mango ${ }^{[46,47,60,62]}$.

We can finally conclude that the occurrence of anthracnose on dragon fruit in Peninsular Malaysia was more influenced by environmental conditions and agricultural practices rather than climatic factors. In spite of the weather parameters change could affect the pathogen, the host as well as the interaction between pathogen and host ${ }^{[63,64]}$, in some cases a relationship between environmental parameters and diseases occurrence was difficult to determine ${ }^{[59]}$. The climate change might be even less important compared with major technological, environmental and socioeconomic changes affecting agricultural production on the next century ${ }^{[64]}$.

\section{CONCLUSION}

Although anthracnose disease on three different species of dragon fruit caused by $C$. gloeosporioides was distributed mostly in all surveyed dragon fruitgrowing areas in Peninsular Malaysia, the highest 
occurrence was recorded from Malacca state; while the lowest prevalence was found in Kelantan state. This study also concluded that the occurrence and progress of disease were highly influenced by environmental conditions as well as agricultural practices.

\section{ACKNOWLEDGEMENT}

The researchers appreciate and thank to Ministry of Higher Education, Malaysia for funding this research under Fundamental Research Grant Scheme (FRGS) vot 5523095 .

\section{REFERENCES}

1. Mizrahi, Y., A. Nerd and P.S. Nobel, 1997. Cacti as crops. Hort. Rev., 18: 291-319. http://www.fao.org/agris/search/display.do?f=./199 8/v2403/US1997055184.xml;US1997055184.

2. Crane, J.H. and C.F. Balerdi, 2005. The pitaya (Hylocereus undatus and other spp.) in Florida. http://miami-

dade.ifas.ufl.edu/pdfs/tropical_fruit/THE\%20PITA YA\%20in\%.

3. Paull, R.E., 2007. Dragon fruit. http://www.twowests.co.uk/weblog/archives/2006/ 07/dragon_fruit.html.

4. Jacobs, D., 1999. Pitaya (Hylocereus undatus), a potential new crop for Australia. http://www.newcrops.uq.edu.au/newslett/ncn11163.htm.

5. de Andrade, R.A., A.B.G. Martins and M.T.H. Silva, 2007. Influence of the material source and the cicatrize time in vegetative propagation of red dragon fruit (Hylocereus undatus Haw). Rev. Bras. Frutic., 29: 183-186. http://www.fao.org/agris/search/display.do?f=./200 8/BR/BR0717.xml;BR2007003066.

6. Le Bellec, F., F. Vaillant and E. Imbert, 2006. Pitahaya (Hylocereus spp.): A new fruit crop, a market with a future. Fruit, 60: 237-250. DOI: 10.1051/fruits:2006021.

7. Esquivel, P., 2004. The fruit of cacti and its potential as raw material. Agron. Am., 15: 215219.

http://www.mag.go.cr/rev_meso/v15n02_215.pdf.

8. Mohamed-Yasseen, Y., 2002. Micropropagation of pitaya (Hylocereus undatus Britton and Rose). In Vitro Cell. Dev. Biol. Plant, 38: 427-429. DOI: 10.1079/IVP2002312.

9. Raveh, E., J. Weiss, A. Nerd and Y. Mizrahi, 1993. Pitayas (Genus Hylocereus): A New Fruit Crop for the Negev Desert of Israel. In: New Crops, Janick, J. and J.E. Simon (Eds.). Wiley, New York, pp: 491-495. ISBN: 0-471-59374-5.
10. Shimomura, T. and K. Fujihara, 1980. Stimulation of axillary shoot formation of cuttings of Hylocereus trigonus (Cactaceae) by pre-soaking in benzyladenine solution. Sci. Hortic., 13: 289-296. http://www.fao.org/agris/search/display.do?f=./198 1/v702/XE8082631.xml;XE8082631.

11. Govinden, N., 2007. Pitaya: A new exotic fruit from

Mauritius. http://www.msiri.mu/Userfiles/file/Pitayadoc2007. pdf?phpMyAdmin=7226189b7750985478c5d0a2d d5baa7b.

12. De Dios, H.C., 2005. A new subspecies of Hylocereus undatus (Cactaceae) from southeastern Mexico. Haseltonia, 11: 11-17. DOI: 10.2985/1070-0048.

13. Barbeau, G., 1990. Frutas en Nicaragua. Editoral Ciencias Sociales. Managua, Nicaragua. http://vianica.com/sp/go/specials/14-frutas-de nicaragua.html.

14. Yen, C.R., 2007. Fruit crops resources in taiwan: cultivation of new fruit crops. Agricultural Extension Committee of National Pingtung University of Science and Technology, Pingtung, Taiwan. Agric. Extension Bul., 41: 56. ISBN: 978986-01-1450-8.

15. Merten, S., 2003. A review of Hylocereus production in the United States. J. PACD., 2003: 98-105. http://www.jpacd.org/V5P98-105.pdf.

16. Nguyen, D.L., 2006. Current difficulties and solutions for enhancing production and export of Vietnamese fruit. Proceedings of International Seminar on Enhancing Export Competitiveness of Asian Fruits, May 18-19, Bangkok, Thailand, pp: 34-46. http://www.unapcaem.org/Activities\%20Files/A22/ p33_VietNamfruit.pdf.

17. Cheah, L.S. and W.M. Zulkarnain, 2008. Status of pitaya cultivation in Malaysia. Paper presented at Seminar on Pitaya Production, Market and ExportChallenges and Prospects, Oct. 20, Putrajaya, Malaysia.

http://itfnet.org/source/mainpage/newsAndEvent/c ontents/PDF_Pitaya_Seminar/Status\%20of\%20pita ya\%20cultivation\%20in\%20Malaysia.pdf.

18. Nerd, A., Y. Sitrit, R.A. Kaushik and Y. Mizrahi, 2002. High summer temperatures inhibit flowering in vine pitaya crops (Hylocereus spp.). Sci. Hortic., 96: 343-350. DOI: 10.1016/S0304-4238(02)00093-6.

19. Liou, M.R., C.L. Hung and R.F. Liou, 2001. First report of Cactus virus $X$ on Hylocereus undatus (Cactaceae) in Taiwan. Plant Dis., 85: 229. DOI: 10.1094/PDIS.2001.85.2.229A.

20. Wang, C.L. and C.C. Lin, 2005. Fruit rot of pitaya and stem rot of cacti in Taiwan. Plant Pathol. Bull., 14: 269-274. http://www.tari.gov.tw/cpps/pdf/144/p269-274.pdf. 
21. Taba, S., N. Miyahira, K. Nasu, T. Takushi and Z. Moromizato, 2007. Fruit rot of strawberry pear caused by Bipolaris cactivora. J. Gen Plant Pathol., 73: 374-376. DOI: 10.1007/s10327-007-0032-x.

22. Valencia-Botin, A.J., J.S. Sandoval-Islas, E. Cardenas-Soriano, T.J. Michailides and G. Rendon-Sanchez, 2003. Botryosphaeria dothidea causing stem spots on Hylocereus undatus in Mexico. Plant Pathol., 52: 803-803. DOI: 10.1111/j.1365-3059.2003.00912.x.

23. Taba, S., D. Mikami, K. Takaesu, A. Ooshiro, Z. Moromizato, S. Nakasone and S. Kawano, 2006. Anthracnose of pitaya (Hylocereus undatus) by Colletotrichum gloeosporioides. Jap. J. Phytopathol., 72: 25-27. http://sciencelinks.jp/jeast/article/200606/000020060606A0170733.php.

24. Palmateer, A.J., R.C. Ploetz, E. van Santen and J.C. Corell, 2007. First report of anthracnose caused by Colletotrichum gloeosporioides on Pitahaya. $\quad$ Plant Dis., $91 \quad$ (5): 631. DOI: 10.1094/PDIS-91-5-0631A.

25. Takahashi, L.M., D.D. Rosa, M.A. Basseto, H.G. de Souza and E.L. Furtado, 2008. First report of Colletotrichum gloeosporioides on Hylocereus megalanthus in Brazil. Aust. Plant Dis. Notes, $\quad 3$ 96-97. http://www.publish.csiro.au/journals/apdn.

26. Chuah, T.G., H.L. Ling, N.L. Chin, T.S.Y. Choong and A. Fakhru'l-Razi. 2008. Effects of temperature on rheological behavior of dragon fruit (Hylocereus sp.) juice. Int. J. Food Eng., 4: 1-28. DOI: 10.2202/1556-3758.1519.

27. Novita, M., S.H. Ahmad, P.Ding and M.R.A. Halim, 2008. Maturity indices and related characteristics of pitaya. Paper presented at Seminar on Pitaya Production, Market and Export-Challenges and Prospects, Oct. 20, Putrajaya, Malaysia. http://itfnet.org/source/mainpage/newsAndEvent/co ntents/PDF_Pitaya_Seminar/Maturity\%20Pitaya.pdf.

28. Novita, M., S.H. Ahmad, P. Ding and M.R.A. Halim, 2006. Physico-chemical changes of red pitaya fruit (Hylocereus polyrhizus). Proceedings of the Congress on Agriculture, Dec. 12-15, Putrajaya, Malaysia, pp: 49-51.ISBN: 983-3455-76-x.

29. Ching, K.M. and R.M. Yusof, 2005. Effect of red pitaya fruit supplementation on lipids profiles of induced hypercholesterolemic rats. In: Abstracts of the $20^{\text {th }}$ Scientific Conference of the Nutrition Society of Malaysia. Mar. 24-25, Kuala Lumpur, Malaysia, $\quad$ pp: 1-92. http://66.102.1.104/scholar?hl=en\&lr=\&q=cache:t HiVVRgpTWgJ:nutriweb.org.my/publications/mjn 0011_1/supplements.pdf.
30. Ariffin, A.A., J. Bakar, C.P. Tan, R.A. Rahman, R. Karim and C. C. Loi, 2009. Essential fatty acids of pitaya (dragon fruit) seed oil. J. Food Chem., 114: 561-564. DOI: 10.1016/j.foodchem.2008.09.108.

31. Harivaindaran, K.H., O.P.S. Rebecca and S. Chandran, 2008. Study of optimal temperature, $\mathrm{pH}$ and stability of dragon fruit (Hylocereus polyrhizus) peel for use as potential natural colorant. Pak. J. Biol. $\quad$ Sci., $\quad$ 11: 2259-2263. http://www.scialert.net/qredirect.php?doi=pjbs.200 $8.2259 .2263 \&$ linkid=pdf.

32. Rebecca, O.P.S., R. Zuliana, A.N. Boyce and S. Chandran, 2008. Determining pigment extraction efficiency and pigment stability of dragon fruit (Hylocereus polyrhizus). J. Biol. Sci., $8:$ 1174-1180. http://www.scialert.net/qredirect.php?doi=jbs.2008. 1174.1180\&linkid=pdf.

33. Martini, M.Y., R.A. Halim, L.Y. Ling, L.Y. and M. Zainudin, 2004. Dragon fruit: Current status and future prospects in Malaysia. Proceeding of the Congress on Agriculture, Oct. 4-7, Sri Kembangan, Selangor Darul Ehsan, Malaysia, pp: 45-48. ISBN: 983-3280-00-5.

34. Masratul Hawa, M., P.Y. Hew, Z. Latiffah, Z. Maziah, H.D. Nagao and B. Salleh, 2008. Aethiology of new disease on red-fleshed dragon fruit (Hylocereus polyrhizus) caused by Fusarium proliferatum. Proceeding of the 7th International Conference on Plant Protection in the Tropics, Aug. 27-29, Kuala Lumpur, Malaysia, pp: 21. http://www.mapps.org.my.

35. Cooke, B.M., 2006. Disease Assessment and Yield Loss. In: The Epidemiology of Plant Diseases, Cooke, B.M., D.G. Jones and B. Kaye (Eds.). 2nd Edn., Springer, Netherlands, ISBN: 10 1-40204580-8, pp: 43-80.

36. Bowen, K.L., 2007. Plant Disease Epidemiology. In: Plant Pathology, Concepts and Laboratory Exercises, Trigiano, R.N., M.T. Windham and A.S. Windham (Eds.). 2nd Edn., CRC Press, New York, ISBN: 9781420046694, pp: 281-294.

37. Kranz, J., 1988. Measuring Plant Disease. In: Experimental Techniques in Plant Disease Epidemiology, Kranz J. and J. Rotem (Eds.). Springer, Berlin, ISBN: 978-0-387-18128-8, pp: 35-50.

38. Melanie, L., L. Ivey, C. Nava-Diaz and S.A. Miller, 2004. Identification and management of Colletotrichum acutatum on immature bell peppers. Plant Dis., 88: 1198-1204. DOI: 10.1094/PDIS.2004.88.11.1198. 
39. Cardoso, J.E., A.A. Santos, A.G. Rossetti and J.C. Vidal, 2004. Relationship between incidence and severity of cashew gummosis in semiarid north-eastern Brazil. Plant Pathol., 53: 363-367. DOI: 10.1111/j.0032-0862.2004.01007.x.

40. SPSS, 2008. SPSS statistical software, version 15.0 for Windows. CD-ROM, Universal product identifiers, part number: 32130.

41. Sutton, B.C., 1992. The Genus Glomerella and its Anamorph Colletotrichum. In: Colletotrichum Biology, Pathology and Control, Bailey, J.A. and M.J. Jeger (Eds.). CAB International, Wallingford, ISBN: 10: 0851987567, pp: 402.

42. Kim, Y.H. and K.H. Kim, 2002. Abscission layer formation as a resistance response of Peruvian apple cactus against Glomerella cingulata. Phytopathology, 92: 964-969. DOI: 10.1094/PHYTO.2002.92.9.964.

43. Kim, W.G., W.D. Cho, H.J. Jee and S.Y. Hong, 2000. Occurrence of anthracnose on indian fig cactus caused by Glomerella cingulata and Colletotrichum gloeosporioides. Plant Pathol. J., 16: 294-296.

http://www.riceblast.snu.ac.kr/file/44/43120_16(5) -10.pdf.

44. Kim, Y.H., O.K. Jun, M.J. Sung, J.S. Shin, J.H. Kim and M.I. Jeoung, 2000. Occurrence of Colletotrichum stem rot caused by Glomerella cingulata on graft-cactus in Korea. Plant Pathol. J., 16: 242-245.

http://www.riceblast.snu.ac.kr/file/44/43098_242.pdf.

45. Seem, R.C., 1984. Disease incidence and severity relationships. Ann. Rev. Phytopathol., 22: 133-150. DOI:10.1146/annurev.py.22.090184.001025.

46. Fitzell, R.D. and C.M. Peak, 1984. The epidemiology of anthracnose disease of mango: Inoculum sources, spore production and dispersal. Ann. Applied Biol., 104: 53-59. DOI: 10.1111/j.1744-7348.1984.tb05586.x.

47. Estrada, A.B., J.C. Dodd and P. Jeffries, 2000. Effect of humidity and temperature on conidial germination and appressorium development of two Philippine isolates of the mango anthracnose pathogen Colletotrichum gloeosporioides. Plant Pathol., 49: 608-618. DOI: 10.1046/j.13653059.2000.00492.x.

48. Guyot, J., E.N. Omandab and F. Pinard. 2005. Some epidemiological investigations on Colletotrichum leaf disease on rubber tree. Crop Protect., 24: 65-77.

DOI: $10.1016 /$ j.cropro.2004.06.009.
49. Fitzell, R.D., 1987. Epidemiology of anthracnose disease of avocados. South African Avocado Growers' Association Yearbook, 10: 113-116.

50. Boland, R.M., S. Chakraborty and J.A.G. Irwin, 1995. Survival of Colletotrichum gloeosporioides on Stylosanthes scabra cv. Fitzroy during the dry season. Aust. J. Agric. Res., 46: 959-969. DOI: 10.1071/AR9950959.

51. Chowdhury, M.N.A., M.A. Rahim, K.M. Khalequzzaman, M.J. Alam and M.R. Humauan, 2008. Effect of horticultural practices on incidence of anthracnose on yield and quality of mango. Int. J. Sustain. Crop Prod., 3: 1-9. http://www.gwf.org.bd/IJSCP/Vol3I2Feb2008/1-9.pdf.

52. Wastie, R.L., 1972. Secondary leaf fall of Hevea brasiliensis: Meteorological and other factors affecting infection by Colletotrichum gloeosporioides. Ann. Applied Biol., 72: 283-293. DOI: 10.1111/j.1744-7348.1972.tb01295.x.

53. Agrios, G.N., 2005. Plant Pathology. 5th Edn., Elsevier Academic Press, Oxford, ISBN: 0-12044565-4, pp: 257.

54. Chandra Mohanan, R., K.M. Kaveriappa and K.K.N. Nambiar, 1989. Epidemiological studies of Colletotrichum gloeosporioides disease on cocoa. Annu. Applied Biol., 114: 15-22. DOI:10.1111/j.1744-7348.1989.tb06783.x.

55. Chakraborty, S. and L. Billard, 1995. Quantitative relationships between Colletotrichum gloeosporioides, infection of Stylosanthes scabra and weather under field conditions. Plant Pathol., 44: 63-72. DOI: $10.1111 / \mathrm{j} .1365-$ 3059.1995.tb02716.x.

56. Srinivasan, N. and M. Gunasekaran, 1996. Incidence of fungal species associated with leaf rot disease of coconut palms in relation to weather and the stage of lesion development. Ann. Applied Biol., 129: 433-449. DOI: 10.1111/j.17447348.1996.tb05766.x.

57. Denham, T.G. and J.M. Waller, 1981. Some epidemiological aspects of post-bloom fruit drop disease (Colletotrichum gloeosporioides) in citrus. Annu. Applied Biol., 98: 65-77. DOI: 10.1111/j.1744-7348.1981.tb00423.x.

58. Irwin, J.A.G., D.F. Cameron and D. Ratcliff, 1984. Influence of environmental factors on the development of the anthracnose diseases of Stylosanthes spp. Aust. J. Agric. Res., 35: 473-478. DOI: 10.1071/AR9840473.

59. Davis, R.D., J.A.G. Irwin, D.F. Cameron and R.K. Shepherd, 1987. Epidemiological studies on the anthracnose diseases of Stylosanthes spp. caused by Colletotrichum gloeosporioides in North Queensland and pathogenic specialization within the natural fungal populations. Aust. J. Agric. Res., 38: 1019-1032. DOI: 10.1071/AR9871019. 
60. Akem, C.N., 2006. Mango anthracnose disease: present status and future research priorities. Plant Pathol. J., 5: 266-273. http://www.scialert.net/qredirect.php?doi=ppj.2006 $.266 .273 \&$ linkid=pdf.

61. Sangeetha, C.G. and R.D. Rawal, 2008. Nutritional studies of Colletotrichum gloeosporioides (Penz.) Penz. and Sacc., the incitant of mango anthracnose. World J. Agric. Sci., 4: 717-720. http://www.idosi.org/wjas/wjas4(6)/8.pdf.

62. Dodd, J.C., A.B. Estrada, J. Matcham, P. Jeffries and M.J. Jeger, 1991. The effect of climatic factors on Colletotrichum gloeosporioides, causal agent of mango anthracnose, in the Philippines. Plant Pathol., 40: 568-575. DOI: 10.1111/j.13653059.1991.tb02421.x.
63. Colhoun, J., 1973. Effects of environmental factors on plant disease. Ann. Rev. Phytopathol., 11: 343364. DOI: 10.1146/annurev.py.11.090173.002015.

64. Coakley, S.M., H. Scherm and S. Chakraborty, 1999. Climate change and plant disease management. Annu. Rev. Phytopathol., 37: 399-426. DOI:10.1146/annurev.phyto.37.1.399. 